Biannual Research Journal Grassroots

Vol.55, No.I, 2021: 186-198

Grassroots

\title{
A STUDY OF SOCIO-ECONOMIC PROBLEMS FACED BY LABORS IN BRICK KILN: A CASE STUDY OF DISTRICT HYDERABAD (RURAL)
}

\author{
Dr.Ghazala Pahawar \\ Associate Professor, Department of Sociology, University of Sindh, Jamshoro \\ Email: ghazalapanhwar@hotmail.com \\ Dr.Shabana Tunio \\ Assistant Professor, Department of Sociology, University of Sindh, Jamshoro \\ Email:shabana.tunio@usindh.edu.pk \\ Muhammad Ali Shaikh \\ Lecturer, Department of Rural Sociology \\ Sindh Agriculture University Tandojam
}

\begin{abstract}
The present study investigates the socio-economic problems of the labors in Brick Kilns which are situated in the vicinities of district Hyderabad (Rural). Eighty three respondents from twenty five brick kilns were selected for interview. It is found that majority of the respondents was illiterate and never visited educational, technical and religious institutions. The economic categorization of the labors revealed that majority was categorized as 'poorest of poor' (living below poverty line), having semi-pacca houses, earning less than 10,000 rupees per month to manage their entire family. Due to very low income they spent least amount on education and health while more on food and utilities. The general problems reported by the labors are: poor quality of drinking water, no shelter at work place, child labor, low and late payment of wages, long working hours etc. Besides these, both male and female labors informed about misbehave and use of abusive language by the owner/manager, even few of them also complained about physical abuse. Stomach problem was found as common disease in men followed by Anemia whereas in women Anemia was ranked first followed by Backache.
\end{abstract}

Keywords: Socio-Economic, Labor, Brick Kiln, Hyderabad.

\section{INTRODUCTION}

In this modern world, the labor working at brick kilns are living most deprived life and mostly called bonded debtors who do not have access to basic needs and rights such as healthy food, good cloth, better shelter, health and education (Sharma, 1999). They are vulnerable to hazardous health, ignorance, no social contacts, bitter socialization of children and no ambition for tomorrow (SPARC, 2006). 
Although the design, shape and weight of bricks have undergone numerous historical changes, the production technology has experienced very limited changes (Mitha et.al., 1989; Hamid and Narmeen, 1993). Bricks are prepared, processed and baked at the brick kiln. Being situated in the remote country side, the brick kiln industry portrays a unique model of industrial relations. The organization of work is highly influenced by socio-cultural factors. Generally poor in nature, all categories of kiln labor, both salaried workers and piecerated labor take substantial advances, both at the time of joining a kiln as well as subsequently. These advance payments take the shape of loan due to high interest rate, manipulation in record from owner / manager of kiln and due to low wages. Due to this, the families of labors become virtual prisoners of the owner and are subject to physical, economic and social exploitation (Usman et.al., 2015). The clutches of debt are so severe that the families cannot get themselves out of the debt for generations in spite of the hard work they put in by even engaging their women and children (Kevin, 1998; Singh, 2005).

More than six thousand brick kilns are reported in Pakistan. The average number of families living ate brick kilns are 25 at each site. The brick kilns generally are situated in desolate places away from the main cities and towns. The working days are around two-third of the year excluding rainy days and monsoon season. They are not paid for the days they don't work (Khattak, 2009). Brick making is a low-paid job. Even after involving the whole family members in making bricks for the whole day, only the one person, who is called as the household, gets a very little amount. This situation reflects that the labors are living their lives under poor conditions (Yousaf, 2014). A limited number of the workers have a written contract and the rest have a verbal understanding. Remuneration is fixed on the basis of the number of bricks made/carried. On average, workers have to work for 11-13 hours (Khattak, 2009; Yousaf, 2014). It was also reported in the literature that the labor in brick kilns has no social and economic status and even they are living below the survival life (Singh, 2005). Only $7 \%$ boys and $6 \%$ girls of school - age living in the brick kiln were found to be enrolled at schools (Awan, 2010). The living conditions of the workers were also in very poor shape and exacerbated the hazards faced by them at working place.

In view of the facts stated above, the study was carried out in Taluka Hyderabad (Rural), with the objectives: (i) To identify out the socio-economic problems faced by workers of Brick kilns in the study 
area, and (ii) To suggest remedial measures and develop suggestions for the welfare of the Brick kiln workers.

\section{MATERIALS AND METHODS}

Sample Size and Data Collection: The cross-sectional study design was adopted to collect the primary data through a follow up survey from the field by using well-structured questionnaire. The parameters such as payment of wages, monthly income, working conditions, residential status, household composition, number of family members, education status, health and general problems faced by the labor etc were mainly considered while questionnaire was developed.

Initially, the brick kilns of Taluka Hyderabad (Rural) were searched and there were 25 brick kilns found functioning which are situated in the vicinities of Hyderabad i.e., Tandojam, Moosa Khatian, and Tando Hyder. A sample size of 82 respondents was managed. The collected data were analyzed by using Statistical Package for Social Sciences (SPSS).

Distribution of Sample Size: The following table shows the distribution of brick kilns and the number of respondents selected from each brick kiln for the purpose of interview. 3 (12\%), 5 (20\%) and 17 $(68 \%)$ brick kilns were selected from Tandojam, Moosa Moosa Khatian and Tando Hyder along with 9 (10.98\%), 17 (20.73\%) and 56 $(68.29 \%)$ respondents from these areas, respectively.

TABLE-1

SAMPLE SIZE: BRICK KILNS SELECTED FROM THREE MAJOR AREAS OF BRICK KILN ESTABLISHMENT OF TALUKA HYDERABAD (RURAL)

\begin{tabular}{|l|c|c|}
\hline Area & No. of Brick Kilns (\%) & No. of Respondents (\%) \\
\hline Tandojam & $3(12.00)$ & $9(10.98)$ \\
\hline Moosa Khatian & $5(20.00)$ & $17(20.73)$ \\
\hline Tando Hyder & $17(68.00)$ & $56(68.29)$ \\
\hline Total & $\mathbf{2 5 ( 1 0 0 . 0 0 )}$ & $\mathbf{8 2}(\mathbf{1 0 0 . 0 0 )}$ \\
\hline
\end{tabular}

Source: Research Study

\section{RESULTS AND DISCUSSIONS}

Literacy Rate: During survey, labours working at the brick kilns were enquired about their education and their responses were recorded in Table 2. Majority (69.51\%) of the respondents was illiterate and 
they have never visited school; and only 15.85 percent passed primary school education; while only 9.76 percent could reach middle school for education. However, 4.88 percent of the respondents could only enrolled in high school and hardly completed the matriculation. None of the 82 respondents could enter college for education, and similar situation was in the case of technical education and religious education.

TABLE-2

LITERACY RATE AMONG RESPONDENT LABOR WORKING AT THE BRICK KILNS IN THE STUDY AREA

\begin{tabular}{|l|c|c|}
\hline Educational level & Number & Percent \\
\hline Illiterate & 57 & 69.51 \\
\hline Primary education & 13 & 15.85 \\
\hline Middle school education & 8 & 9.76 \\
\hline High school education & 4 & 4.88 \\
\hline College education & 0 & 0.00 \\
\hline Technical education & 0 & 0.00 \\
\hline Religious education & 0 & 0.00 \\
\hline Total & $\mathbf{8 2}$ & $\mathbf{1 0 0 . 0 0}$ \\
\hline
\end{tabular}

Source: Research Study

Housing Status: Housing is one of the major aspects in life of the human being that contributes mainly his natural satisfaction for living. The data regarding the housing status shown in Table 3 suggest that majority $(60.98 \%)$ of the respondents in the study area are living at brick kiln sites at the lowest standard of living. Moreover, 32.93 percent of these labours having their own houses because they are settled permanently in the suburban areas of the brick kilns. However, around 6 percent labours are reported to live on rented houses.

TABLE-3

HOUSING STATUS OF THE LABOR AT THE BRICK KILNS IN THE STUDY AREA

\begin{tabular}{|l|c|c|}
\hline Housing condition & Number & Percent \\
\hline Own house & 27 & 32.93 \\
\hline Rented house & 5 & 6.10 \\
\hline Living at Brick kiln site & 50 & 60.98 \\
\hline Total & $\mathbf{8 2}$ & $\mathbf{1 0 0 . 0 0}$ \\
\hline
\end{tabular}

Source: Research Study 
Housing Type: The housing type used by the brick kiln workers as their residence was examined during the survey and the responses are reported in Table 4. It is obvious from the results that majority of the brick kiln workers $(67.07 \%)$ are living in a semi-pacca house (some portion constructed of bricks and most of the construction is based on clay) followed by $25.61 \%$ who lives in katcha (made of clay) house. Only 7.32 percent of these workers were reportedly living in pacca (cemented) houses.

TABLE-4

TYPE OF HOUSE USED AS RESIDENCE BY THE LABOR AT THE BRICK KILNS IN THE STUDY AREA

\begin{tabular}{|l|c|c|}
\hline Housing type & Number & Percent \\
\hline Pacca & 6 & 7.32 \\
\hline Semi-Pacca & 55 & 67.07 \\
\hline Katcha & 21 & 25.61 \\
\hline Total & $\mathbf{8 2}$ & $\mathbf{1 0 0 . 0 0}$ \\
\hline \multicolumn{2}{|c|}{ Source: Research Study } \\
\hline
\end{tabular}

Family Composition of the Household Heads of the Labour: Family composition of household heads of the labour working at the brick kilns is reported in Table 5. It was observed that majority of the household heads $(37.80 \%)$ possesses families up to 7 members, followed by 9 members $(30.49 \%)$.

TABLE-5

FAMILY COMPOSITION OF HOUSEHOLD HEADS OF THE LABOUR WORKING AT THE BRICK KILNS

\begin{tabular}{|l|c|c|}
\hline Family members & Number & Percent \\
\hline $3-5$ & 4 & 4.88 \\
\hline $5-7$ & 31 & 37.80 \\
\hline $7-9$ & 25 & 30.49 \\
\hline $9-11$ & 14 & 17.07 \\
\hline Above 11 & 8 & 9.76 \\
\hline Total & $\mathbf{8 2}$ & $\mathbf{1 0 0 . 0 0}$ \\
\hline
\end{tabular}

Likewise, $17.07 \%$ of the families are consisted of 9 to 11 members and nearly $10 \%$ percent of the household heads have families composed of more than 11 members. The lowest percentage (approximately 5\%) was reported for the families having 3-5 members. 
This indicates that that they have no concept of family planning and due to large number of family members they are deprived to involve their women and children to work.

Monthly Income of Household Heads of the Labors: The responses regarding the average monthly income of the respondents are presented in Table 6. It is observed that a majority of the household heads earning less than 10,000 rupees per month to manage their entire family and living life below the poverty level. It can be seen in the table that 10.09 percent household heads earning up to 5000 rupees per month. Likewise, $17.07 \%, 20.73 \%, 18.29 \%, 13.41 \%$ and $10.98 \%$ of household heads earning monthly income up to 7000, 9000, 10000, 12000 and 14000 rupees, respectively. Equally 2.44 percent of the household heads of the labours earned monthly income up to 16000 , 18000 and 20000 rupees. Only 1.22 percent household heads earned more than 20000 rupees per month.

TABLE-6

MONTHLY INCOME OF HOUSEHOLD HEAD OF THE LABOR WORKING AT THE BRICK KILNS

\begin{tabular}{|l|c|c|c|}
\hline Household income & $\begin{array}{c}\text { No. of } \\
\text { respondents }\end{array}$ & Percent & $\begin{array}{c}\text { Av. Income per } \\
\text { household }\end{array}$ \\
\hline Less than 5000 & 9 & 10.98 & 4629.63 \\
\hline $5000-7000$ & 14 & 17.07 & 5825.24 \\
\hline $7000-9000$ & 17 & 20.73 & 7766.99 \\
\hline $9000-10000$ & 15 & 18.29 & 9223.30 \\
\hline $10000-12000$ & 11 & 13.41 & 10679.60 \\
\hline $12000-14000$ & 9 & 10.98 & 12621.40 \\
\hline $14000-16000$ & 2 & 2.44 & 14563.10 \\
\hline $16000-18000$ & 2 & 2.44 & 16504.90 \\
\hline $18000-20000$ & 2 & 2.44 & 18446.60 \\
\hline 20000 and above & 1 & 1.22 & 21359.20 \\
\hline Total & $\mathbf{8 2}$ & $\mathbf{1 0 0 . 0 0}$ & $\mathbf{1 2 1 6 2 . 0}$ \\
\hline
\end{tabular}

Source: Research Study

Monthly Expenditure of Household Heads of Labor: The information regarding the monthly expenditure of respondents is presented in Table 7. The table showed that 60.50 percent of the total monthly income earned by the household heads spent on food items, followed by utility bills and 15.33 percent of the monthly household 
income is spent on payment of electricity bills etc. On average, the household heads of the labor spent 8.70 percent of their monthly income on clothing, 5.14 percent on transportation, 4.67 percent on social functions, 3.46 percent on health and only 2.20 percent they spent on education of their children. This indicates that education was the least preferred and a minor amount was spent on educational activities of their children. Similar situation was observed for their health activities and they spent meagre amount on health and hygiene.

TABLE-7

MONTHLY EXPENDITURE OF HOUSEHOLD HEADS OF THE LABOR WORKING AT THE BRICK KILNS

\begin{tabular}{|l|c|c|}
\hline Items of expenditure & Expenditure (Rs.) & Percent \\
\hline Food & 7358 & 60.50 \\
\hline Transportation & 625 & 5.14 \\
\hline Social Function & 568 & 4.67 \\
\hline Health & 421 & 3.46 \\
\hline Education & 267 & 2.20 \\
\hline Clothing & 1058 & 8.70 \\
\hline Utility Bills & 1865 & 15.33 \\
\hline Total & $\mathbf{1 2 1 6 2}$ & $\mathbf{1 0 0 . 0 0}$ \\
\hline
\end{tabular}

Source: Research Study

Economic Categorization of the Labor Working at Brick Kilns: The results for the economic categorization of the household of labors working at brick kiln are reported in Table 8 . It can be seen from the table that majority $(62.20 \%)$ of the labor were categorized as 'poorest of poor' (as they live even below poverty line) and nearly quarter $(25.61 \%)$ of the respondents were categorized as 'poor' and this category is just better than those live on poverty line. Likewise, 12.20 percent of the labor working falls in the 'average' economic category. This indicates that 87.81 percent of the labor falls either in the 'poorest of poor' or in the 'poor' economic category. None of them was reported to live well-off or rich life. This situation is extremely vulnerable and harassing in regards to economic development among the labor communities. 


TABLE-8
ECONOMIC CATEGORY OF LABOR WORKING AT BRICK KILNS IN
\begin{tabular}{|l|c|c|}
\hline THE STUDY AREA \\
\hline Category & Number & Percent \\
\hline Poorest of poor & 51 & 62.20 \\
\hline Poor & 21 & 25.61 \\
\hline Average & 10 & 12.20 \\
\hline Well-off & 0 & 0.00 \\
\hline Rich & 0 & 0.00 \\
\hline Total & $\mathbf{8 2}$ & $\mathbf{1 0 0 . 0 0}$ \\
\hline
\end{tabular}

Behavior of Brick Kiln Owner/Manager Towards Labor: When the brick kiln labors (both male and female) was asked about the behavior of owner / manager with them, the following segregated responses were observed and reported in Table 9. The table shows that 88.46 percent male labors, abusing by the owner/manager is a common practice and they are habitual to bear such type of attitude; while 42.31 percent male labor disclosed that owner of the brick kiln abuses on advance payments and they use both verbal and physical abuse. It was disclosed by 44.23 percent male labor that the manager uses abusive language to adult also while 17.31 percent complained that the manager abuses children and sometimes beat them.

TABLE-9

BEHAVIOR OF OWNERS/MANAGER WITH LABORS WORKING AT BRICK KILNS

\begin{tabular}{|l|c|c|c|c|}
\hline \multicolumn{1}{|c|}{ Particulars } & \multicolumn{2}{c|}{ Male } & \multicolumn{2}{c|}{ Female } \\
\cline { 2 - 5 } & $\mathbf{N}$ & $\mathbf{\%}$ & $\mathbf{N}$ & $\mathbf{\%}$ \\
\hline Owner/ manager misbehave on advance payment & 22 & 42.31 & 25 & 83.33 \\
\hline Insult and punish & 5 & 9.62 & 7 & 23.33 \\
\hline Misbehave/insult a common practice over here & 46 & 88.46 & 16 & 53.33 \\
\hline Both verbal and physical & 22 & 42.31 & 3 & 10.00 \\
\hline $\begin{array}{l}\text { Manager misbehave children and sometimes beat } \\
\text { them }\end{array}$ & 9 & 17.31 & 9 & 30.00 \\
\hline Manager uses abusive language to adult also & 23 & 44.23 & 14 & 46.67 \\
\hline Manager misbehave women & 2 & 3.85 & 11 & 36.67 \\
\hline We are habitual to bear due to daily routine & 46 & 88.46 & 29 & 96.67 \\
\hline Sexual harassment & 0 & 0.00 & 0 & 0.00 \\
\hline
\end{tabular}

Source: Research Study 
Similarly, the female labor were also enquired and put before them the same questions and 83.33 percent females complained that owner/ manager abuse due to advance payments and 96.67 percent disclosed that they are habitual to bear abusive attitude of the manager because this is routine practice by them. The women labor (46.67\%) also disclosed that manager uses abusive language to adult females; 36.67 percent indicated that manager abuses the females; and 30.00 percent disclosed that they also sometimes beat the children on their little mistake. However, 53.33 disclosed that abuse is a common practice at the brick kilns. Around quarter (23.33 percent) of the women labor indicated that the manager abuse and punish them for common reasons. It is surprising to know that none of the respondents has complaint about sexual harassment.

Health Problems in Male and Female Labors: Anemia, stomach disorders, backache, pain in legs, skin problems and breathing problems were the common health problems both in the male and female labor at the brick kilns in the study areas. In male labors, 67.31 percent were suffering from stomach problem followed by Anemia $(61.54 \%)$, pain in legs $(42.31 \%)$, backache problem $(32.69 \%)$, cough $(25.00 \%)$, and skin problem $(23.08 \%)$.

So far as the female labors are concerned, majority (86.67\%) of them is suffering from Anemia followed by backache $(76.67 \%)$, pain in legs $(50.00 \%)$, pain in joints which is also known as Arthritis $(43.33 \%)$. About one-fourth of the female respondents complained for muscular pain and 16.67 percent disclosed swelling in body. 


TABLE-10
HEALTH PROBLEMS FACED BY MALE AND FEMALE LABOR AT
BRICK KILNS
\begin{tabular}{|l|c|c|c|c|}
\hline \multirow{2}{*}{ Health problems (n=82) } & \multicolumn{2}{c|}{ Male (n=52) } & \multicolumn{2}{c|}{ Female (n=30) } \\
\cline { 2 - 5 } & N & $\%$ & N & $\%$ \\
\hline Backache & 17 & 32.69 & 23 & 76.67 \\
\hline Fever & 6 & 11.54 & 1 & 3.33 \\
\hline Eye infection & 6 & 11.54 & 0 & 0.00 \\
\hline Ear infection & 2 & 3.85 & 2 & 6.67 \\
\hline Watery eyes & 7 & 13.46 & 4 & 13.33 \\
\hline Cough & 13 & 25.00 & 7 & 23.33 \\
\hline Asthma & 4 & 7.69 & 3 & 10.00 \\
\hline Skin problem & 12 & 23.08 & 11 & 36.67 \\
\hline Breathing problem & 6 & 11.54 & 10 & 33.33 \\
\hline Stiff neck & 5 & 9.62 & 2 & 6.67 \\
\hline Anemia & 32 & 61.54 & 26 & 86.67 \\
\hline Pain in legs & 22 & 42.31 & 15 & 50.00 \\
\hline Pain in joint & 3 & 5.77 & 13 & 43.33 \\
\hline Swelling in some body & 7 & 13.46 & 5 & 16.67 \\
\hline Pain in chest & 6 & 11.54 & 1 & 3.33 \\
\hline Stomach problem & 35 & 67.31 & 10 & 33.33 \\
\hline Muscular pain & 1 & 1.92 & 8 & 26.67 \\
\hline Exhaustion & 11 & 21.15 & 0 & 0.00 \\
\hline High blood pressure & 9 & 17.31 & 3 & 10.00 \\
\hline
\end{tabular}

Source: Research Study

\section{General Problems Faced by Labor at Brick Kiln \\ TABLE-11}

GENERAL PROBLEMS FACED BY LABOR AT BRICK KILN IN THE STUDY AREAS $(\mathbf{N}=82)$

\begin{tabular}{|l|c|c|}
\hline Problems faced by labor & Number (N) & Percent (\%) \\
\hline Poor quality drinking water & 78 & 95.12 \\
\hline No shelter at work place & 61 & 74.39 \\
\hline Poor working conditions & 80 & 97.56 \\
\hline No education facility & 72 & 87.80 \\
\hline Severe health problems & 78 & 95.12 \\
\hline Lost contacts with relatives & 49 & 59.76 \\
\hline Child labour & 82 & 100.00 \\
\hline Poor living conditions & 81 & 98.78 \\
\hline Women / children face harassment / abuse & 54 & 65.85 \\
\hline Drug addiction & 29 & 35.37 \\
\hline Low wages & 82 & 100.00 \\
\hline Payment not given in time & 54 & 65.85 \\
\hline Working hours are long & 56 & 68.29 \\
\hline
\end{tabular}

Source: Research Study 
Finally, the labor working in the brick kilns were enquired about the general problem faced by them and their responses are reported in Table 11. It was observed that labor were aware of the real problems and losses and 100 percent labor indicated that their children lost future due to involvement in work (child labor) and also for low wage rate whereas 98.78 percent of them disclosed that poor living condition is another major problem. Similarly, 97.56, 95.12, 95.12, 87.80 and 74.39 perceived that poor working conditions, poor quality drinking water, severe health problems, no education facility, and no shelter at work place, respectively were also among their major problems. Some other problems including women and children face harassment/abuse, delayed payment of wages and too long working hours are also highlighted by them.

\section{CONCLUSIONS}

The present study shows that education which is considered as the basic right of every human being was extremely vulnerable in case of labors of brick kiln as none of the respondents could enter into the college for education, and similar situation was in the case of technical education and religious education. The general living condition of the brick kiln workers is worse and attention of the relevant public authorities is needed to improve the situation. Overwhelming majority of the brick kiln workers are living in a structurally and materially low standard houses; even one room was allocated for families consisting of huge members. High majority of the household heads related to the labor working at the brick kilns earning meagre amount of monthly income to manage their entire family and living life below the poverty level.

This situation is extremely vulnerable and harassing in regards to economic development among the labor communities. Females also complained that the owners of brick kilns abuse them verbally and physically as well. Sexual harassment was reported neither from the male labor nor from the women labor. This indicates that the health problems were more in the females as compared to males. Eye infection was reported in male labor and not in females; exhaustion was reported in males and not in females, high blood pressure was more in males than their females. However, Asthma problem was more in females than the males. 
The general problems faced by the labor working in brick kilns are ranked as: children lost future due to involvement in work, low wage rate, poor living conditions, poor working conditions, poor quality drinking water, severe health problems, no education facility, no shelter at work place, women and children face harassment/ abuse, delayed payment of wages, too long working hours etc.

\section{SUGGESTIONS}

Hence, the general living condition of the brick kiln workers is worse and attention of the relevant public authorities is needed to improve the situation. Based on the finding presented in this study, it is highly recommended that government should take concrete steps in order to improve the living standard of the labors working at brick kiln. It is the equal responsibility of the NGOs working basically for human rights should play their role to convey the problems to higher authorities especially by taking into consideration the basic rights of shelter, health, education and food. The law enforcement agencies should take notification regarding the implementation of rules made to protect the labors of brick kiln from inhuman behavior of their owners/ managers.

\section{REFERENCES}

Awan, S.A. (2010). Gender dimensions of bonded labor in brick kilns in Punjab province of Pakistan. Report of a research and analytical study, Center for Improvement of Working Conditions \& Environment (CIWCE), Lahore Pakistan.

Hamid, A. \& Narmeen, A. (1993). Health and Industrial Status of Working Children in Brick Kilns, Carpet Weaving Industry and Garages. A medical study conducted in Lahore and in collaboration with the Islamic Welfare Society, Lahore and UNICEF.

Kevin, B. (1998). Disposable People, New Slavery in the Global Economy. University of California Press Berkeley/Los Angeles/London.

Khattak, S.G. (2009). Social analysis of the brick production units in Pakistan. Proc. 12 ${ }^{\text {th }}$ Sustainable Development Conference (SDC) 2009, 21-23 Dec. 2012, Islamabad Pakistan.

Mitha, Y., Anwar, M., Nighat, S., \& Javed, A. (1989). Solid Foundations Solid Contributions; Women in the Brick Kiln Industry. ASR, Lahore.

Sharma, D.K., Varun, A., \& Patel, M. (2013). Qualitative study on clinico-social problems of brick-kiln workers: a study from Anand, Gujarat. National Journal of Community Medicine, 4(3): 503-511. 
Singh, D.P. (2005). Buried in bricks: A rapid assessment of bonded labor in Afghan brick kilns. Journal of Gender Studies, 12(1): 83-97.

SPARC, 2006. Society for the Protection of the Rights of the Child, The State of Pakistan's Children in 2005: Islamabad.

Usman, A., Kataria, J.R., Awan, H., Hussain, S., \& Usman, M. (2015). Elimination of Bonded Labor in South Asia: The Process Patronage and Laborers' Right to Access Micro Credit in Brick Kiln Industry of Pakistan. Journal of South Asian Studies, 30(1) :71-80.

Yousaf, S. (2014). Brick kiln industry in Pakistan. Pakistan Christian Congress. Retrieved on $2^{\text {nd }}$ March 2, 2014 from: http://www.pakistanchristianpost. $\underline{\text { com/viewarticles.php?editorialid }=341}$ 